\title{
PERSONAL AND OCCUPATIONAL RISK FACTORS FOR CARPAL TUNNEL SYNDROME IN MEAT PROCESSING INDUSTRY WORKERS IN NORTHERN ITALY
}

\author{
${ }^{1}$ Provincial Agency for Health Services of the Autonomous Province of Trento, Trento, Italy \\ Department of Prevention, Occupational Health and Safety Unit \\ ${ }^{2}$ University of Parma, Parma, Italy \\ Department of Biomedical, Biotechnological and Translational Sciences
}

\begin{abstract}
Background: Carpal tunnel syndrome (CTS) is a musculoskeletal condition that often impairs the fitness to work. Our aim is to retrospectively evaluate the association between physical exposures in meat processing industry in Northern Italy and the CTS, taking into account non-occupational factors. Material and Methods: A cross-sectional study was performed to include 434 workers (236 males, 198 females, $37.0 \pm 10.6$ years old, working age: $12.6 \pm 10.8$ years) from meat processing industries. Signs and symptoms were collected at the compulsory occupational medical surveillance. Occupational risk factors were assessed through a questionnaire and direct assessment by investigators. Adjusted odds ratios $\left(\mathrm{OR}_{\mathrm{ad}}\right)$ for factors of interest were estimated through binary logistic regression. Results: Diagnosis of the CTS was reported for 61 out of 434 subjects (14.1\%) for an incidence of $11.3 / 1000$ person-years. In general, signs and symptoms for the CTS were associated with the following demographic factors: smoking history $(\mathrm{OR}=1.909,95 \%$ confidence interval $(\mathrm{CI}): 1.107-3.293)$, previous traumas of the upper limb $(\mathrm{OR}=3.533,95 \% \mathrm{CI}: 1.743-7.165)$, hypothyroidism status ( $\mathrm{OR}=7.897,95 \% \mathrm{CI}: 2.917-21.38)$ and, in the case of female participants only, previous pregnancies $(\mathrm{OR}=2.807,95 \% \mathrm{CI}: 1.200-6.566)$ as well as a personal history of oral contraceptive therapy and/or steroidal replacement therapy $(\mathrm{OR}=11.57,95 \% \mathrm{CI}: 4.689-28.56)$. The carpal tunnel syndrome cases were associated with the following occupational factors (> $4 \mathrm{~h}$ /day): forceful hand exertion $\left(\mathrm{OR}_{\mathrm{adj}}=3.548,95 \% \mathrm{CI}: 1.379-9.131\right)$, repeated trauma of the hand $\left(\mathrm{OR}_{\mathrm{adj}}=3.602,95 \% \mathrm{CI}: 1.248-\right.$ $10.395)$, repeated movements of the wrist $\left(\mathrm{OR}_{\mathrm{adj}}=2.561,95 \% \mathrm{CI}: 1.100-5.960\right)$. Conclusions: Increasing levels of hand activity and force were associated with the increased CTS prevalence among participants. Recommendations have to be provided in order to reduce occupational exposure to these risk factors and improve medical surveillance. Med Pr 2017;68(2):199-209
\end{abstract}

Key words: cumulative trauma disorders, peripheral nervous system disease, electromyography, carpal tunnel syndrome, nerve compression syndromes, meat-packing industry

Corresponding author: Matteo Riccò, Provincial Agency for Health Services of the Autonomous Province of Trento, Department of Prevention, Occupational Health and Safety Unit, Via Verona SNC, C/O Centro Servizi Sanitari, 38123 Trento, Italy, e-mail: mricco2000@gmail.com

Received: August 1, 2016, accepted: December 4, 2016

\section{INTRODUCTION}

With an estimated prevalence of $1-5 \%$ in the general population, the carpal tunnel syndrome (CTS) is considered to be the most common form of peripheral nerve entrapment neuropathy, representing a significant driver of workers' compensation costs, lost time, lost productivity and disability [1-3]. In the US only, medical costs for the CTS have been estimated to amount to 2 billion dollars annually, primarily due to surgical releases [4], and the median sick leave from the CTS is $25-27$ days, which is longer than any other workrelated disorder except fractures $[5,6]$.

Clinically, the CTS has been defined as a complex of symptoms (i.e., pain, numbness, or tingling on the anterior surface of the index, middle, or radial half of the ring finger, frequently associated with weakness of hand grip, and nocturnal pain and/or numbness) resulting from compression of the median nerve at the carpal tunnel formed by the carpal bones and the transverse ligament [7-9]. Although age, female gender, body mass index (BMI), diabetes mellitus, rheumatoid arthritis, hyperthyroidism, and previous wrist surgery, have been repetitively recognized as main risk factors for the CTS $[6,10,11]$, sound evidence associates such disorder with workplace factors such as repetitive/prolonged hand-intensive activities, forceful exertions, awkward and/or static postures, vibrations, temperature extremes, and localized mechanical stress CTS [3,7,8,12-16].

Not coincidentally, the prevalence of electrophysiological confirmed that the CTS in working populations is generally higher than in the general population [17], 
and in certain working groups it may peak up to around $20 \%$ [18-20]. In this regard, meat processing industry has been repetitively identified as a high risk environment for the CTS, as it typically requires significant exposure to repetitive hand movements to hang, kill, clean, eviscerate, cut, package and box meat at a rapid pace and at relatively low environmental temperature [6,21-23]. Not coincidentally, the CTS prevalence in meat industry has been reported to be $15-24 \%$ [2,3,10,18-20,23-27], and some reports suggest that even higher estimates may be found depending on the operative definition applied by researchers $[20,21,28,29]$.

Italian meat industry employs around 30000 workers in 5000 establishments across the country, representing about $5 \%$ of pork $10 \%$ of poultry production in the EU. The average size of the enterprises is small, with a median of 12 employees per establishment, even smaller than the European median size of 20 employees, ultimately forcing the workers to perform several tasks during the working shift, implying a relatively low degree of specialization [30-32].

Despite these specificities, data regarding the CTS epidemiology in meat processing industry in Italy is still lacking [33]. The objective of this study has therefore been to investigate the epidemiology of the CTS among workers of small-sized meat processing establishments in Northern Italy, and to assess whether personal risk factors may be associated with the CTS diagnosis.

\section{MATERIAL AND METHODS}

Workers from 31 meat processing plants referring to one occupational health service from Northern Italy (median size $=11$ employees) were recruited between January 2012 and December 2013. This convenience sample included only employees directly involved in meat processing tasks, such as cutting, eviscerating, washing, trimming, deboning, receiving, hanging, killing, plucking, packing, sanitation, chilling, eventually encompassing a total of 473 consecutive subjects. Inclusion criteria included being at least 18 years old, Italian speaking, working at least $24 \mathrm{~h} /$ week for at least 3 years of seniority in meat processing industry. Exclusion criteria included contraindication to receiving nerve conduction studies (NCS), such as known coagulopathies, bloody discrasias, current oral anticoagulant therapy, or an implanted cardiac defibrillator.

All the subjects were informed about the study and people agreeing to participate signed an informed con- sent. The study protocol included: occupational risk assessment, clinical evaluation and electrodiagnostic study of the median nerve. Clinical and electrodiagnostic examinations were performed by different operators, blinded to each other's results.

\section{Clinical assessment}

The clinical evaluation of each worker was performed by a properly trained clinician. All patients received a full medical assessment in order to obtain a complete musculoskeletal evaluation. Patients referring to symptoms such as numbness, tingling, burning or pain in at least 1 of 1st, 2nd or 3rd digit, palm or wrist pain and having a positive Phalen's test and/or positive reverse Phalen's test, and/or positive Tinel's test, and/or positive Carpal Compression test, were considered clinically possible cases of the CTS and further evaluations with ultrasonography and/or NCS were performed [15,34-38]. For the purposes of this survey, the NCS diagnosis of the CTS was achieved by motor latencies $>4.0 \mathrm{~ms}$, sensory latencies $>3.7 \mathrm{~ms}$, amplitudes $<20 \mu \mathrm{V}$, or a conduction velocity $<50 \mathrm{~m} / \mathrm{s}$ with evidence of fibrillation [35]. A case of the CTS was defined by a worker, not by hand.

A questionnaire was administered to all workers in order to standardize data collection about demographic characters, pain condition, medical history (i.e., thyroid problems, kidney failure, diabetes mellitus, previous pregnancies). Among clinical data, history of previous traumas (i.e., either penetrating or closed injuries associated with at least 10 days of restricted/impaired movements of the arm) or surgical procedures of the upper limb were accurately collected. Data about drug consumption was also recalled, with particular attention to $\beta$-blockers, non-steroidal anti-inflammatory drugs (NSAIDs) and, for females only, oral contraceptive therapy (OCT: at least 5 years of cumulative use) and steroidal replacement therapy (SRT). Regular physical activity was defined following the World Health Organization (WHO) recommendation for those who are 18-64 years old [39].

\section{Exposure assessment}

Information on present and former employment, actual employment status, tasks held at the meat industries, and self-reported ergonomic exposures, was also obtained from the questionnaire. They were then asked to identify and characterize which tasks they performed during the working shift (i.e., cutting, eviscerating, washing, trimming, deboning, receiving, hanging, killing, plucking, packing, sanitation, chilling). 
Working tasks details collected from the questionnaires and workplaces were eventually assessed in order to identify whether the workers were exposed to the following risk factors for at least $4 \mathrm{~h} /$ day:

working in cold environment (i.e., $\mathrm{t}<18^{\circ} \mathrm{C}$ ),

weight lifting having the National Institute for Occupational Safety and Health (NIOSH) lifting in$\operatorname{dex}>1.0$,

forceful hand exertion ( $\geq 10 \mathrm{~N}$ pinch force or $\geq 45 \mathrm{~N}$ grip force),

thumb pressing (i.e., activities requiring the prolonged application of force trough the thumb either on tools or objects),

forearm rotation (i.e., activities requiring supination/pronation of the forearm $>45^{\circ}$ ),

the use of vibrating tools (i.e., visible hand/arm vibration during the use of vibratory hand tools),

prolonged wrist bending (i.e., sustained wrist flexion/extension $>30^{\circ}$ ),

forced position of the wrist (i.e., axial deviation of wrist from neutral position),

repeated trauma of the hand (i.e., repeated mechanical compression of the soft tissues in the hand following the use of tools or objects which press against the palm),

repeated movement of the wrist (i.e., cycle time of less than 30 " or more than $50 \%$ of the cycle time involved performing the same type of fundamental cycles).

All exposure variables were analyzed as dichotomous ones (i.e., present/absent).

\section{Statistical analysis}

Continuous variables were compared using the t-test whereas the $\mathrm{Chi}^{2}$ test was used for comparing categori- cal variables. The univariate analysis was used for calculating the odds ratios (OR) and the 95\% confidence intervals (CI). A binary logistic regression model was then applied in order to calculate the correspondent adjusted odds ratios $\left(\mathrm{OR}_{\mathrm{adj}}\right)$ for occupational risk factors having a $\mathrm{p}<0.20$ in the univariate analysis. The model assumed diagnosis of the CTS as an independent variable, and included sex, age and working age as covariates, as well as all personal risk factors that in the univariate analysis were statistically associated with the CTS positive status $(\mathrm{p}<0.05)$. All statistical analyses were performed using SPSS version 24.0 (IBM Corp.).

\section{Ethics}

The study was performed as a part of a compulsory health assessment at the workplace: the procedures were performed only in order to fully assess the clinical status and the workers' fitness to work, and would be performed even without the conduction of the study. Therefore, no preliminary evaluation by the Ethical Committee was necessary. However, as clinical and personal data had been collected and elaborated, all participants gave their written consent and subjects refusing their consent were excluded from the study population.

\section{RESULTS}

The Table 1 shows the demographics and personal characteristics of the participants. The overall response rate was $91.8 \%$ including a total of 434 workers, and the average age of participants was $37.0 \pm 10.6$ years old, with a mean seniority of $12.6 \pm 10.8$ years. The study population included predominantly subjects of male sex $(\mathrm{N}=236,54.4 \%)$ and Italian origin $(\mathrm{N}=301,69.4 \%)$, ha-

Table 1. Demographic data of meat processing industry workers in the study of personal and occupational risk factors for carpal tunnel syndrome (CTS), Northern Italy, 2012-2013

\begin{tabular}{|c|c|c|c|c|c|c|}
\hline Respondents characteristics & \multicolumn{3}{|c|}{ Respondents } & $\mathrm{p}$ & OR & $95 \%$ CI \\
\hline \multicolumn{7}{|l|}{$\operatorname{Sex}[\mathrm{n}(\%)]$} \\
\hline males & $236(54.4)$ & $209(88.6)$ & $27(11.4)$ & 0.087 & 0.623 & $0.361-1.075$ \\
\hline Italian-born people & $301(69.4)$ & $254(84.4)$ & $47(15.6)$ & 0.160 & 1.573 & $0.833-2.969$ \\
\hline foreign-born people & $133(31.6)$ & $119(89.5)$ & $14(10.5)$ & & & \\
\hline Age [years] $(\mathrm{M} \pm \mathrm{SD})$ & $37.0 \pm 10.6$ & $35.6 \pm 10.0$ & $46.0 \pm 9.8$ & $<0.001$ & & \\
\hline
\end{tabular}


Table 1. Demographic data of meat processing industry workers in the study of personal and occupational risk factors for carpal tunnel syndrome (CTS), Northern Italy, 2012-2013 - cont.

\begin{tabular}{|c|c|c|c|c|c|c|}
\hline \multirow[b]{2}{*}{ Respondents characteristics } & \multicolumn{3}{|c|}{ Respondents } & \multirow[b]{2}{*}{$\mathrm{p}$} & \multirow[b]{2}{*}{ OR } & \multirow[b]{2}{*}{$95 \% \mathrm{CI}$} \\
\hline & $\begin{array}{c}\text { total } \\
(\mathrm{N}=434)\end{array}$ & $\begin{array}{l}\text { asymptomatic } \\
\qquad(\mathrm{N}=373)\end{array}$ & $\begin{array}{l}\text { with clinically } \\
\text { assessed CTS } \\
(\mathrm{N}=61)\end{array}$ & & & \\
\hline Seniority [years] $(\mathrm{M} \pm \mathrm{SD})$ & $12.6 \pm 10.8$ & $11.1 \pm 10.1$ & $21.6 \pm 10.7$ & $<0.001$ & & \\
\hline \multicolumn{7}{|l|}{ Body mass index (BMI) } \\
\hline $\mathrm{M} \pm \mathrm{SD}\left[\mathrm{kg} / \mathrm{m}^{2}\right]$ & $24.4 \pm 3.7$ & $24.3 \pm 3.8$ & $24.3 \pm 3.1$ & 0.368 & & \\
\hline overweight $\left(\mathrm{BMI}>25 \mathrm{~kg} / \mathrm{m}^{2}\right)[\mathrm{n}(\%)]$ & $161(37.1)$ & $133(82.6)$ & $28(17.4)$ & 0.125 & 1.531 & $0.887-2.644$ \\
\hline obesity $\left(\mathrm{BMI}>30 \mathrm{~kg} / \mathrm{m}^{2}\right)[\mathrm{n}(\%)]$ & $38(8.8)$ & $35(92.1)$ & $3(7.9)$ & 0.253 & 0.500 & $0.149-1.678$ \\
\hline \multicolumn{7}{|l|}{ Personal risk factors [n (\%)] } \\
\hline smoking history (current or previous) & $162(37.3)$ & $131(80.9)$ & $31(19.1)$ & 0.019 & 1.909 & $1.107-3.293$ \\
\hline previous trauma(s) of the upper limbs & $43(9.9)$ & $29(67.4)$ & $14(32.6)$ & $<0.001$ & 3.533 & $1.743-7.165$ \\
\hline previous surgery of the upper limbs & $3(0.7)$ & $2(66.7)$ & $1(33.3)$ & 0.336 & 3.083 & $0.275-34.550$ \\
\hline no physical activity & $399(91.9)$ & $348(87.2)$ & $51(12.9)$ & 0.158 & 0.495 & $0.213-1.148$ \\
\hline previous diagnosis of thyroid disease & $17(3.9)$ & $9(52.9)$ & $8(47.1)$ & $<0.001$ & 7.897 & $2.917-21.380$ \\
\hline previous diagnosis of diabetes & $4(0.9)$ & $3(75.0)$ & $1(25.0)$ & 0.527 & 2.056 & $0.210-20.100$ \\
\hline previous pregnancies* & $114(57.6)$ & $88(77.2)$ & $26(22.8)$ & 0.014 & 2.807 & $1.200-6.566$ \\
\hline $\begin{array}{l}\text { previous use of oral contraceptive therapy / } \\
\text { hormone replacement therapy (OCT/HRT)* }\end{array}$ & $68(34.3)$ & $41(60.3)$ & $27(39.7)$ & $<0.001$ & 11.570 & $4.689-28.560$ \\
\hline previous use of $\beta$-blockers & $15(3.4)$ & $10(66.7)$ & $5(33.3)$ & 0.029 & 3.241 & $1.068-9.835$ \\
\hline $\begin{array}{l}\text { chronic use of non steroidal anti- } \\
\text { inflammatory drugs (NSAIDs) }\end{array}$ & $30(6.9)$ & $21(70.0)$ & $9(30.0)$ & $<0.001$ & 21.230 & $9.107-49.510$ \\
\hline
\end{tabular}

$\mathrm{M}$ - mean, SD - standard deviation, OR - odds ratio, CI - confidence interval.

* Female participants only.

ving a mean body mass index (BMI) of $24.4 \pm 3.7 \mathrm{~kg} / \mathrm{m}^{2}$. Twenty-one cases had a personal history of comorbid conditions (4.8\%), including the previous diagnosis of thyroid disease $(\mathrm{N}=17,3.9 \%)$ and diabetes mellitus $(\mathrm{N}=4,0.9 \%)$. A total of 35 workers referred to regular physical activity (8.1\%), and most of the participants were never smokers $(\mathrm{N}=272,62.7 \%)$.

Among the participants (Table 2), most worked in a cold environment (i.e., $\left.<18^{\circ} \mathrm{C}\right)(\mathrm{N}=281,64.7 \%)$, and performed activities that required weight lifting for at least $4 \mathrm{~h} /$ day $(\mathrm{N}=262,60.4 \%)$ whereas the use of vibrating tools was identified for 127 out of 434 workers (29.3\%). Daily tasks requiring the prolonged application of force trough the thumb either on tools or objects, and repeated mechanical compression of the soft tissues in the hand were identified in $39.9 \%(\mathrm{~N}=173)$ and $27 \%(\mathrm{~N}=117)$ of the participants, respectively. Focusing on hand/wrist movement and postures, forceful hand exertion was identified in $55.3 \%$ patients $(\mathrm{N}=240)$ whereas 33.9\% $(\mathrm{N}=147)$ of the participants performed activities implying supination/pronation of the forearm $>45^{\circ}$ from neutral position, $26.5 \%(\mathrm{~N}=115)$ of workers had daily tasks including prolonged wrist bending, $16.6 \%(\mathrm{~N}=72)$ performed activities that forced the axial wrist posture, and $12.2 \%(\mathrm{~N}=53)$ executed repeated movement of the wrist.

The workers meeting the case definition for the CTS diagnosis were 61 out of 434 subjects (14.1\%), and more precisely 27 out of 236 males (11.4\%) and 34 out of 198 females $(17.2 \%, p=0.087)$, for an estimated incidence of $11.3 / 1000$ person-years $(9.6 / 1000$ person-years among males, and 13.3/1000 person-years among females, $\mathrm{p}=0.208)$. For 34 of them (55.7\%) clinical diagnosis was confirmed by the ultrasonography and/or the nerve conduction study.

The mean age of the 61 employees with the CTS, independent of sex, was $46 \pm 9.8$ years old, with a seniority of $21.6 \pm 10.7$ years whereas asymptomatic workers were significantly younger $(35.6 \pm 10.0$ years, $\mathrm{p}<0.001)$ with a shorter employment history (11.1 \pm 10.1 years, $\mathrm{p}<0.001$ ). In the univariate analysis, no significant relation was found between ethnicity and prevalence of the CTS (69.4\% Italian-born people (IBP) vs. 31.6\% foreign-born people (FBP), $\mathrm{p}=0.160)$. Current and previous smokers $(\mathrm{N}=162)$ had prevalence of the CTS signs and symptoms greater than never-smokers 


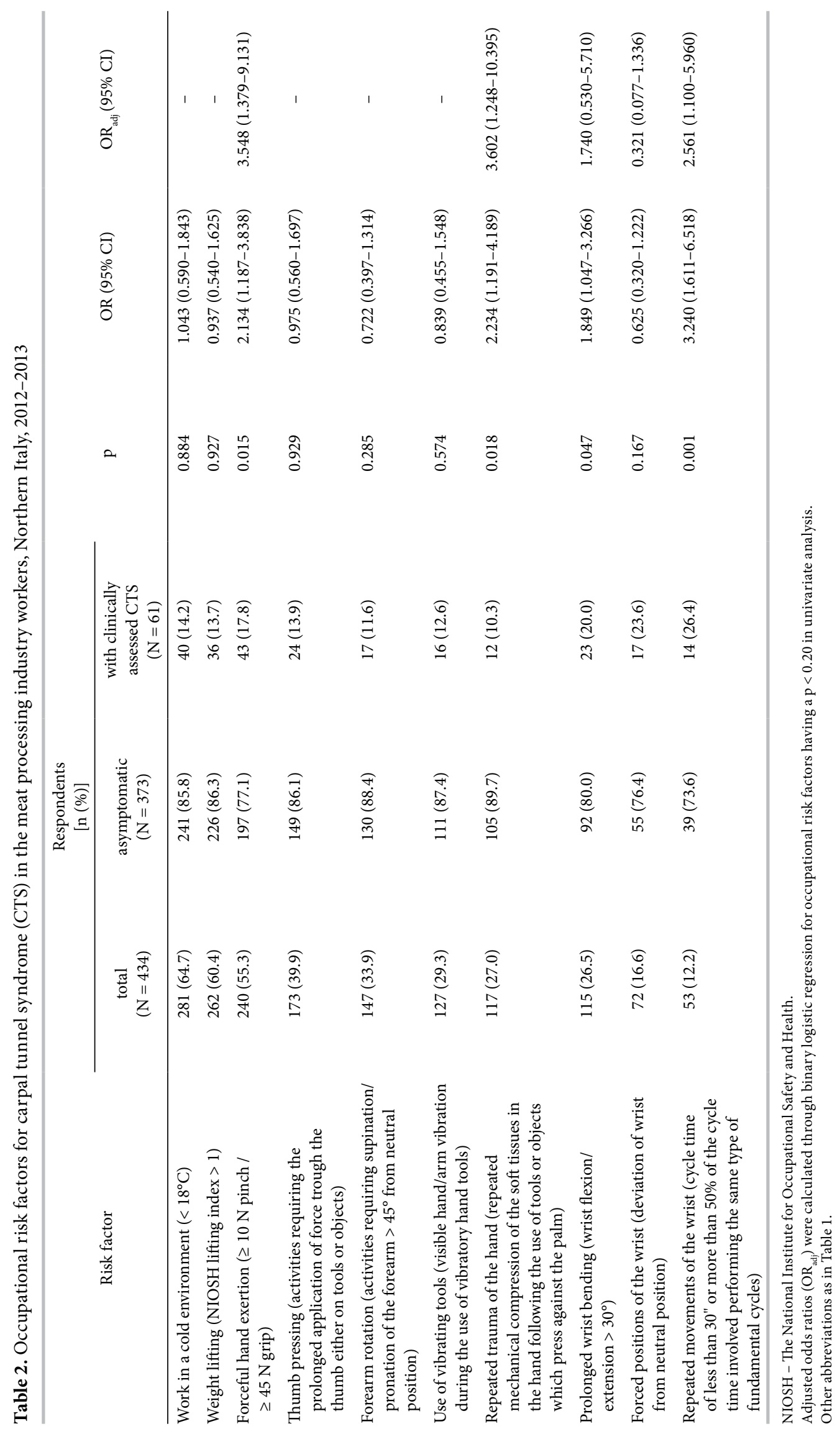


$(\mathrm{N}=272,19.1 \%$ vs. $11.0 \%, \mathrm{p}=0.019, \mathrm{OR}=1.909$, 95\% CI: 1.107-3.293). Personal history positive for previous traumas of the upper limb was recalled by a total of 43 workers (9.9\%), and more specifically by $67.4 \%$ of the CTS cases and $32.6 \%$ of asymptomatic workers $(\mathrm{p}<0.001, \mathrm{OR}=3.533,95 \%$ CI: $1.743-7.165)$.

The body mass index of the CTS cases and the CTS negative workers was similar $\left(24.3 \pm 3.8 \mathrm{~kg} / \mathrm{m}^{2}\right.$ vs. $24.3 \pm 3.1 \mathrm{~kg} / \mathrm{m}^{2}, \mathrm{p}=0.368$ ), and overweight (defined as BMI $\left.\geq 25 \mathrm{~kg} / \mathrm{m}^{2}\right)$ and obesity $\left(B M I \geq 30 \mathrm{~kg} / \mathrm{m}^{2}\right)$ status was not significantly associated with the CTS diagnosis $(\mathrm{OR}=1.531,95 \% \mathrm{CI}: 0.887-2.644$ and $\mathrm{OR}=0.500$, 95\% CI: 0.149-1.678, respectively). Conversely, a previous diagnosis of hypothyroidism was more frequently reported in the CTS positive than in the CTS negative cases $(\mathrm{OR}=7.897,95 \% \mathrm{CI}$ : 2.917-21.38).

Regarding pharmacological history, chronic use of NSAIDs and $\beta$-blocker therapy previous to the diagnosis of the CTS was recalled by 30 (6.9\%) participants and 15 (3.4\%) participants, respectively. Both exposures were positively associated with the CTS status $(\mathrm{p}<0.001)$.

Among female participants, a personal history including one or more pregnancies previous to the beginning of clinical symptoms as well as personal history of oral contraceptive therapy/hormone replacement therapy $(\mathrm{OCT} / \mathrm{HRT})(\mathrm{p}<0.001, \mathrm{OR}=11.57$, 95\% CI: 4.689-28.56) were more frequently referred to by the CTS positive cases ( $76.5 \%$ vs. $53.7 \%$, OR $=2.807$, 95\% CI: 1.200-6.566).

Focusing on occupational factors (Table 2), the CTS cases were associated with the following occupational factors ( $>4 \mathrm{~h} /$ day): forceful hand exertion $(\mathrm{OR}=2.134$, 95\% CI: 1.187-3.838), repeated trauma of the hand $(\mathrm{OR}=2.234,95 \% \mathrm{CI}: 1.191-4.189)$, prolonged wrist bending $(\mathrm{OR}=1.849,95 \% \mathrm{CI}: 1.047-3.266)$, and repeated movements of the wrist (OR $=3.240,95 \%$ CI: $1.611-$ 6.618) whereas the CTS positive and negative cases had similar exposure to factors such as working in a cold environment $(\mathrm{OR}=1.043$, 95\% CI: 0.590-1.843), weight lifting (OR $=0.937,95 \% \mathrm{CI}: 0.540-1.625)$, thumb pressing $(\mathrm{OR}=0.975,95 \% \mathrm{CI}: 0.560-1.697)$, forced positions of the wrist (OR $=0.625,95 \% \mathrm{CI}: 0.320-1.222)$ and forearm rotation $(\mathrm{OR}=0.722$, 95\% CI: $0.397-1.314)$ as well as the use of vibrating tools $(\mathrm{OR}=0.839,95 \% \mathrm{CI}$ : $0.455-$ 1.548).

Eventually, the logistic regression was modeled including age and working age, personal risk factors (including: history of previous traumas/previous surgery of the upper limb, chronic diseases, smoking history, regular physical activity at the time of the survey). Adjusted estimates for forceful hand exertion $\left(\mathrm{OR}_{\mathrm{adj}}=3.548\right.$, 95\% CI: 1.379-9.131), repeated trauma of the hand $\left(\mathrm{OR}_{\mathrm{adj}}=3.602\right.$, 95\% CI: 1.248-10.395), repeated movements of the wrist $\left(\mathrm{OR}_{\mathrm{adj}}=2.561,95 \% \mathrm{CI}: 1.100-5.960\right)$ retained statistical significance.

\section{DISCUSSION}

The work-related CTS has been reported in meat processing workers since 1983, and the following research has confirmed a significantly increased occupational risk $[3,40]$. Available studies on meat industry workers have defined the CTS by different criteria, such as recalling of symptoms, examination findings in a physical examination, nerve conduction studies, neuromuscular ultrasound studies, response to surgery, or by a combination of these parameters, resulting in large differences in epidemiological data $[3,6,20,21,33,41,42]$. Our definition of the CTS was constructed to reflect what may be called a common clinical consensus of what is usually understood as the CTS, and showed a prevalence of $14.1 \%$, and an incidence of 11.3 cases $/ 1000$ person-years. This incidence is more than three times the one reported in the general population of Siena during the decade 1991-1998, a study that ultimately based the CTS diagnosis on nerve conduction studies, and somehow similar to other reports from meat processing industry $[3,6,20,21,33,41-43]$. However, our results should be cautiously interpreted.

First of all, we must stress that the CTS is a very common condition in the general population, and our sample was relatively small, obtained through a sort of convenience sampling, as included workers who were enlisted for the compulsory medical surveillance of enterprises referring to the same occupational medicine service $[2,37,44-47]$. However, as the participation rate was $>90 \%$, selection bias was presumptively reduced [6].

Secondly, the percentage rate of comorbid conditions otherwise associated with the CTS, such as diabetes and hypothyroidism, was relatively small both for cases and asymptomatic workers, and probably it represents a healthy worker effect $[8,9,38,43,48-51]$, eventually suggesting a significant "survivor bias." In other words, as our study included people who were able to maintain their jobs and lost those who left the employment because of clinical conditions or other reasons, we may have ultimately underestimated both incidence and prevalence of the CTS. 
Finally, it should be stressed that a clear consensus about the best clinical criteria for diagnosis of the CTS still does not exist $[35,51,52]$. In our study, the clinical assessment $[15,34-38]$ was followed by ultrasonography and/or NCS study, and only $55.7 \%$ of cases were eventually defined as the CTS-confirmed cases, suggesting that the clinical estimates may be biased by a significant overdiagnosis. As previously reported, despite the general reliance on NCS/electromyography as diagnostic gold standards, when electrodiagnostic tests are performed in order to validate the results of the physical exams, they are potentially biased by the clinical diagnosis and its inherent variability $[52,53]$. In other terms, an even more cautious approach is required not only when comparing our results to national estimates but also when referring to similar studies $[2,3,10,18-20,23-27]$.

In our sample, traditional risk factors for the CTS such as higher age and BMI were unrelated to prevalence and incidence of the CTS. It is possible that the manual labour performed in the various tasks associated with meat processing industry represents a greater risk factor for the CTS, as suggested by the greater seniority of the CTS cases, and previously reported in other studies about the CTS epidemiology in occupations requiring forceful exertion [1,2,21]. Actually, we observed a significant risk of the CTS for workers performing task implying forceful hand exertion, repeated trauma of the hand, and repeated movements of the wrist, but our results are partially consistent with previous studies, as we failed to recognize a correlation of the CTS with the use of a vibrating tool, otherwise described as a main risk factor $[2,3,6,20,21,33,41,42]$.

These figures may require several explanations. First of all, long-term forceful or repetitive hand and/or wrist activities would lead to increased interstitial fluid pressure within the carpal tunnel. An increased carpal tunnel pressure would in turn compress its contents, which may lead to poor blood circulation. Over time, ischaemia ultimately causes long-lasting effects such as irreversible damage to the flexor synovial cells and median nerve synovial thickening, with extensive fibrosis and demyelination of the median nerve $[2,7-9,12,54]$. Hand-arm vibrations may also cause similar effects but modern and up-to-date vibrating tools have significantly reduced workers' exposure [27,54-57].

Moreover, Italian meat processing industry is very heterogeneous not only in terms of size but also regarding the application of modern ergonomics in the design of workplaces [33]. In order to minimize this effect, we focused on the specific tasks performed by participants, eventually identifying the specific risk factors. Their presence received a double evaluation, as the questionnairecollected self-assessment was associated with a specific technical appraisal of workplaces but this assessment was unable to accurately characterize previous exposures, and the CTS represents an impairment of body structures associated rather than simply caused by $\mathrm{cu}-$ mulative exposure to work, working environments and several personal risk factors [58]. In this regard, as we adjusted the obtained odds ratios for the most known risk factors of the CTS (i.e., demography, lifestyle factors, medical conditions), the observed association between work-related risk factors and the CTS are unlikely due to confounding by these factors $[3,6,20,21,33,41,42]$.

Despite previous studies that suggested an increased risk for the CTS in female workers, we also found a slightly greater risk for female workers both in terms of prevalence and incidence, the difference being not statistically significant. Among female participants, history of the OCT/HRT and previous pregnancies were more frequently reported by the CTS. These associations are consistent with previous evidences, as the hormonal status has been identified as a significant risk factor for the CTS [59-61]. The use of $\beta$-blockers has been more controversially reported among the risk factors for the CTS since the late 1980's, and the underlying mechanism may similarly result from the drugrelated fluid retention and oedema $[51,62,63]$. The interpretation of the strong association of NSAIDs use with the CTS status appears more controversial. In brief, it is plausible that these figures should be assumed as consequently rather than causatively related: despite NSAIDs are useful only with a substantial degree of tendonitis or tenosynovitis associated with the CTS, patients frequently self-medicate with oral NSAIDs $[51,64]$.

The higher risk for the CTS after upper limb trauma and/or upper limb surgery should also be accurately evaluated, as usually interpreted as a rare issue $[65,66]$. In general, studies about the CTS and trauma have focused on short term complications of trauma involving a pressure increase in the carpal tunnel [66]: as anything that irritates or compresses the median nerve in the carpal tunnel space may lead to carpal tunnel syndrome, these findings hint for a more accurate recall of previous personal history in the case of the CTS patients.

\section{CONCLUSIONS}

In our study, encompassing 434 workers, both prevalence and incidence of the CTS were roughly similar 
to previous reports from meat processing industry, and up to 3 time the estimates for Italian general population, supporting a significant effect of occupational risk factors on the CTS natural history. Personal risk factors such as smoking history, the OCT/HRT, previous pregnancies, metabolic comorbidities, use of $\beta$-blockers, and previous history of traumas and surgical procedures at the upper limb, were associated with the increased risk for the CTS. Our results suggest that strenuous and repetitive nature of meat processing, and in particular forceful hand exertion, repeated trauma of the hand, and repeated movements of the wrist significantly increase the risk for the CTS. As several tasks associated with these risk factors during meat processing may be only marginally automatized or semiautomatized in order to reduce workers' exposure, our results ultimately reinforce the recommendations to employ a rigorous job rotation schedule in which employees rotate between jobs that use different muscle groups, and to increase screening for the CTS in order to monitor and ultimately improve employee health.

\section{REFERENCES}

1. Burt S, Crombie K, Jin Y, Wurzelbacher S, Ramsey J, Deddens J. Workplace and individual risk factors for carpal tunnel syndrome. Occup Environ Med. 2011;68:928-33, https://doi.org/10.1136/oem.2010.063677.

2. Harris-Adamson C, Eisen EA, Kapellusch J, Garg A, Hegmann KT, Thiese MS, et al. Biomechanical risk factors for carpal tunnel syndrome: A pooled study of 2474 workers. Occup Environ Med. 2015;72:33-41, https://doi.org/ 10.1136/oemed-2014-102378.

3. Kim JY, Kim J-I, Son JE, Yun SK. Prevalence of carpal tunnel syndrome in meat and fish processing plants. J Occup Health. 2004;46:230-4, https://doi.org/10.1539/joh.46.230.

4. Dale AM, Ryan D, Welch L, Olsen MA, Buchholz B, Evanoff B. Comparison of musculoskeletal disorder health claims between construction floor layers and a general working population. Occup Environ Med. 2015;72:15-20, https://doi.org/10.1136/oemed-2014-102313.

5. Foley M, Silverstein B, Polissar N. The economic burden of carpal tunnel syndrome: Long-term earnings of CTS claimants in Washington State. Am J Ind Med. 2007;55: 155-73, https://doi.org/10.1002/ajim.20430.

6. Musolin K, Ramsey JG, Wassell JT, Hard DL. Prevalence of carpal tunnel syndrome among employees at a poultry processing plant. Appl Ergon. 2014;45:1377-83, https://doi. org/10.1016/j.apergo.2014.03.005.
7. Chammas M. Carpal tunnel syndrome. Chir Main. 2014; 33:75-94, https://doi.org/10.1016/j.main.2013.11.010.

8. Thurston A. Carpal tunnel syndrome. Orthop Trauma. 2013; 27:332-41, https://doi.org/10.1016/j.mporth.2013.08.003.

9. MacDermid JC, Wessel J. Clinical diagnosis of carpal tunnel syndrome: A systematic review. J Hand Ther. 2004;17: 309-19, https://doi.org/doi:10.1197/j.jht.2004.02.015.

10. Roquelaure Y, Ha C, Nicolas G, Pelier-Cady M-C, Mariot $\mathrm{C}$, Descatha A, et al. Attributable risk of carpal tunnel syndrome according to industry and occupation in a general population. Arthritis Rheum. 2008;59:1341-8, https:// doi.org/10.1002/art.24002.

11. Mattioli S, Baldasseroni A, Curti S, Cooke RMT, Mandes A, Zanardi F, et al. Incidence rates of surgically treated idiopathic carpal tunnel syndrome in blue- and whitecollar workers and housewives in Tuscany, Italy. Occup Environ Med. 2009;66:299-304, https://doi.org/10.1136/ oem.2008.040212.

12. Bickel KD. Carpal tunnel syndrome. J Hand Surg Am. 2010;35:147-52,https://doi.org/10.1016/j.jhsa.2009.11.003.

13. Violante FS, Farioli A, Graziosi F, Marinelli F, Curti S, Armstrong TJ, et al. Carpal tunnel syndrome and manual work: The OCTOPUS cohort, results of a ten-year longitudinal study. Scand J Work Environ Health. 2016;42:28090, https://doi.org/10.5271/sjweh.3566.

14. You D, Smith AH, Rempel D. Meta-analysis: Association between wrist posture and carpal tunnel syndrome among workers. Saf Health Work. 2014;5:27-31, https://doi.org/ 10.1016/j.shaw.2014.01.003.

15. Ghasemirad M, Nosair E, Vegh A, Mohammadi A, Akkad A, Lesha E, et al. A handy review of carpal tunnel syndrome: From anatomy to diagnosis and treatment. World J Radiol 2014;6:284-300, https://doi.org/10.4329/wjr.v6. i6.284.

16. Goodson JT, DeBerard MS, Wheeler AJ, Colledge AL. Occupational and biopsychosocial risk factors for carpal tunnel syndrome. J Occup Environ Med. 2014;56:965-72, https://doi.org/10.1097/JOM.0000000000000202.

17. Bao SS, Kapellusch JM, Merryweather AS, Thiese MS, Garg A, Hegmann KT, et al. Impact of work organizational factors on carpal tunnel syndrome and epicondylitis. J Occup Environ Med. 2016;58(8):760-4, https://doi. org/10.1097/JOM.0000000000000790.

18. Van Rijn RM, Huisstede BM, Koes BW, Burdorf A. Associations between work-related factors and the carpal tunnel syndrome - A systematic review. Scand J Work Environ Health. 2009;35:19-36, https://doi.org/doi:10.5271/ sjweh.1306.

19. Fan ZJ, Harris-Adamson C, Gerr F, Eisen EA, Hegmann KT, Bao S, et al. Associations between workplace factors and 
carpal tunnel syndrome: A multi-site cross sectional study. Am J Ind Med. 2015;58:509-18, https://doi.org/10.1002/ ajim.22443.

20. Gorsche RG, Wiley PJ, Renger RF, Brant RF, Gemer TY, Sasyniuk TM. Prevalence and incidence of carpal tunnel syndrome in a meat packing plant. Occup Environ Med. 1999;56:417-22, https://doi.org/10.1136/oem.56.6.417.

21. Cartwright MS, Walker FO, Newman JC, Schulz MR, Arcury TA, Grzywacz JG, et al. One-year incidence of carpal tunnel syndrome in Latino poultry processing workers and other Latino manual workers. Am J Ind Med. 2014;57: 362-9, https://doi.org/10.1002/ajim.22250.

22. Vogel K, Karltun J, Eklund J, Engkvist IL. Improving meat cutters' work: Changes and effects following an intervention. Appl Ergon. 2013;44:996-1003, https://doi. org/10.1016/j.apergo.2013.03.016.

23. Viikari-Juntura E, Kurppa K, Kuosma E, Huuskonen M, Kuorinka I, Ketola R, et al. Prevalence of epicondylitis and elbow pain in the meat-processing industry. Scand J Work Environ Health. 1991;17:38-45, https://doi.org/10.5271/ sjweh.1736.

24. Dale AM, Harris-Adamson C, Rempel D, Gerr F, Hegmann K, Silverstein B, et al. Prevalence and incidence of carpal tunnel syndrome in US working populations: Pooled analysis of six prospective studies. Scand J Work Environ Health. 2013;39:495-505, https://doi.org/10.5271/sjweh.3351.

25. Thomsen JF, Mikkelsen S, Andersen JH, Fallentin N, Loft IP, Frost P, et al. Risk factors for hand-wrist disorders in repetitive work. Occup Environ Med. 2007;64:527-33, https://doi.org/10.1136/oem.2005.021170.

26. Kurppa K, Viikari-Juntura E, Kuosma E, Huuskonen M, Kivi P. Incidence of tenosynovitis or peritendinitis and epicondylitis in a meat-processing factory. Scand J Work Environ Health. 1991;17:32-7, https://doi.org/10.5271/ sjweh.1737.

27. Fan ZJ, Harris-Adamson C, Gerr F, Eisen EA, Hegmann KT, Bao $S$, et al. Associations between workplace factors and carpal tunnel syndrome: A multi-site cross sectional study. Am J Ind Med. 2015;58:509-18, https://doi.org/10.1002/ ajim.22443.

28. Katz JN, Larson MG, Fossel AH, Liang MH. Validation of a surveillance case definition of carpal tunnel syndrome. Am J Public Health. 1991;81:189-93, https://doi. org/10.2105/AJPH.81.2.189.

29. Yagev Y, Gringolds M, Karakis I, Carel SR. Carpal tunnel syndrome: Under-recognition of occupational risk factors by clinicians. Ind Health. 2007;45:820-2, https://doi. org/10.2486/indhealth.45.820.

30. Brasili C, Fanfani R, Montresor E, Pecci F. The local system of the food industry in Italy. In: Arfini F, Mora C, editors.
Typical and traditional products: Rural effect and agroindustrial problems. Proceedings of the 52nd EAAE Seminar; 1997 Jun 19-21 [Internet]. Parma, Italy. Pisa: Instituto di Economia; 1998. p. 419-40 [cited 2016 Aug 5]. Available from: http://ageconsearch.umn.edu/bitstream/231196/1/ Cristina\%20Brasili,\%20Roberto\%20Fanfani,\%20Elisa\%20 Montresor,\%20Francesco\%20Pecci\%20(1997)\%20The\%20 local\%20systems $\% 20$ of $\% 20$ the $\% 20$ food $\% 20$ industry $\% 2$ 0in\%20Italy.pdf.

31. Associazione Industriali delle Carni e dei Salumi. [Annual report ASSICA]. [Internet]. Milan: The Associazione; 2016 [cited 2016 Aug 5]. Available from: http://www.assica.it/it/ pubblicazioni/rapporto-annuale.php. Italian.

32. European Commission, Enterprise and Industry. Study on the competitiveness of the European meat processing industry. [Internet]. Luxembourg: Publications Office of the European Union; 2011. p. 1-261 [cited 2016 Aug 5]. Available from: http://www.eurocarne.com/daal?a1=informes\& a2=competitividad-en-sector-carnico-europeo.pdf.

33. Isolani L, Bonfiglioli R, Raffi GB, Violante FS. Different case definitions to describe the prevalence of occupational carpal tunnel syndrome in meat industry workers. Int Arch Occup Environ Health. 2002;75:229-34, https://doi. org/10.1007/s00420-001-0304-2.

34. Lawson IJ, Burke F, McGeoch KL, Nilsson T, Proud G. Hand-arm vibration syndromes. In: Baxter PJ, Aw TC, Cockcroft A, Durrington P, Harrington JM, editors. Hunters disease of occupations. 10th ed. London: CRC Press London; 2011. p. 498-512.

35. American Academy of Orthopaedic Surgeons. clinical practice guideline on the diagnosis of carpal tunnel syndrome [Internet]. Rosemont: The Academy; 2007. p. 1-73 [cited 2016 Aug 5]. Available from: http://www.aaos.org/ research/guidelines/cts_guideline.pdf.

36. Rempel D, Evanoff B, Amodio PC, de Krom M, Franklin G, Franzblau A, et al. Consensus criteria for the classification of carpal tunnel syndrome. Am J Public Health. 1998;88: 1447-51, https://doi.org/10.2105/AJPH.88.10.1447.

37. Homan MM, Franzblau A, Werner RA, Albers JW, Armstrong TJ, Bromberg MB. Agreement between symptom surveys, physical examination procedures and electrodiagnostic findings for the carpal tunnel syndrome. Scand J Work Environ Health. 1999;25:115-24, https://doi.org/ 10.5271/sjweh.413.

38. Miedany El Y, Ashour S, Youssef S, Mehanna A, Meky FA. Clinical diagnosis of carpal tunnel syndrome: Old testsnew concepts. Joint Bone Spine. 2008;75:451-7, https://doi. org/10.1016/j.jbspin.2007.09.014.

39. World Health Organization. Global recommendations on physical activity for health [Internet]. Geneva, Switzer- 
land: World Health Organization Press; 2010 [cited 2016 Aug 5]. Available from: http://apps.who.int/iris/bitstre am/10665/44399/1/9789241599979_eng.pdf.

40. Falck B, Aarnio P. Left-sided carpal tunnel syndrome in butchers. Scand J Work Environ Health. 1983;9:291-7, https://doi.org/10.5271/sjweh.2408.

41. Frost P, Andersen JH, Nielsen VK. Occurrence of carpal tunnel syndrome among slaughterhouse workers. SJWEH Suppl. 1998;24:285-92, https://doi.org/10.5271/sjweh.322.

42. Cartwright MS, Walker FO, Blocker JN, Schulz MR, Arcury TA, Grzywacz JG, et al. The prevalence of carpal tunnel syndrome in Latino Poultry-processing workers and other Latino manual workers. J Occup Environ Med. 2012;54:198-201, https://doi.org/10.1097/JOM.0b013e31 $823 f d f 53$.

43. Mondelli M, Giannini F, Giacchi M. Carpal tunnel syndrome incidence in a general population. Neurology. 2002; 58(2):289-94, https://doi.org/10.1212/WNL.58.2.289.

44. Mattioli S, Baldasseroni A, Curti S, Cooke RM, Bena A, de Giacomi G, et al. Incidence rates of in-hospital carpal tunnel syndrome in the general population and possible associations with marital status. BMC Public Health. 2008;8:374, https://doi.org/10.1186/1471-2458-8-374.

45. Mattioli S, Baldasseroni A, Bovenzi M, Curti S, Cooke RM, Campo G, et al. Risk factors for operated carpal tunnel syndrome: A multicenter population-based case-control study. BMC Public Health. 2009;9:343, https://doi.org/10. 1186/1471-2458-9-343.

46. Harris-Adamson C, Eisen EA, Dale AM, Evanoff B, Hegmann KT, Thiese MS, et al. Personal and workplace psychosocial risk factors for carpal tunnel syndrome: A pooled study cohort. Occup Environ Med. 2013;70:529-37, https:// doi.org/10.1136/oemed-2013-101365.

47. Atroshi I, Gummesson C, Johnsson R, Ornstein E, Ranstam J, Rosén I. Prevalence of carpal tunnel syndrome in a general population. JAMA. 1999;282:153-8, https://doi. org/10.1001/jama.282.2.153.

48. Silverstein BA, Fine LJ, Armstrong TJ. Occupational factors and carpal tunnel syndrome. Am J Ind Med. 1987;11: 343-58, https://doi.org/10.1002/ajim.4700110310.

49. Olney RK. Carpal tunnel syndrome: Complex issues with a "simple" condition. Neurology. 2001;56:1431-2, https:// doi.org/10.1212/WNL.56.11.1431.

50. Duckworth AD, Jenkins PJ, McEachan JE. Diagnosing carpal tunnel syndrome. J Hand Surg Am. 2014;39:1403-7, https://doi.org/10.1016/j.jhsa.2014.03.039.

51. LeBlanc KE, Cestia W. Carpal tunnel syndrome. Am Fam Physician. 2011;83:952-8.

52. Glowacki KA, Breen CJ, Sachar J, Weiss AP. Electrodiagnostic testing and carpal tunnel release outcome. J Hand
Surg Am. 1996;21:117-21, https://doi.org/10.1016/S03635023(96)80164-X.

53. Graham B. The value added by electrodiagnostic testing in the diagnosis of carpal tunnel syndrome. J Bone Joint Surg Am. 2008;90:2587-93, https://doi.org/10.2106/ JBJS.G.01362.

54. Petit A, Ha C, Bodin J, Rigouin P, Descatha A, Brunet R, et al. Risk factors for carpal tunnel syndrome related to the work organization: A prospective surveillance study in a large working population. Appl Ergon. 2015;47:1-10, https://doi.org/10.1016/j.apergo.2014.08.007.

55. Lecrlerc A, Franchi P, Cristofari MF, Delemotte B, Mereau P, Teyssier-Cotte $\mathrm{C}$, et al. Carpal tunnel syndrome and work organisation in repetitive work: A cross sectional study in France. Occup Environ Med. 1998;55:180-7, https://doi. org/10.1136/oem.55.3.180.

56. Rigouin P, Ha C, Bodin J, Le Manac'h AP, Descatha A, Goldberg $M$, et al. Organizational and psychosocial risk factors for carpal tunnel syndrome: A cross-sectional study of French workers. Int Arch Occup Environ Health. 2014; 87:147-54, https://doi.org/10.1007/s00420-013-0846-0.

57. Andréu JL, Otón T, Silva-Fernández L, Sanz J. Hand pain other than carpal tunnel syndrome (CTS): The role of occupational factors. Best Pract Res Clin Rheumatol. 2011;25:31-42, https://doi.org/10.1016/j.berh.20 10.12.001.

58. European Agency for Safety and Health at Work. Workrelated musculoskeletal disorders: Prevention report [Internet]. Luxembourg: Office for Official Publications of the European Communities; 2008 [cited 2016 Aug 5]. Available from: https://osha.europa.eu/en/tools-and-publications/ publications/reports/en_TE8107132ENC.pdf.

59. Ferry S, Hannaford P, Warskyj M, Lewis M, Croft P. Carpal tunnel syndrome: A nested case-control study of risk factors in women. Am J Epidemiol. 2000;151:566-74, https:// doi.org/10.1093/oxfordjournals.aje.a010244.

60. Albani G, Priano L, Campanelli L, Pignatti R, Liuzzi A, Galotti P, et al. Carpal tunnel syndrome and oral contraceptive drugs: Risk or protective factor? J Peripher Nerv Syst. 2003;8:208-8, https://doi.org/10.1111/j.10859489.2003.03026.x.

61. Riccò M, Cattani S, Signorelli C. Personal risk factors for carpal tunnel syndrome in female visual display unit workers. Int J Occup Med Environ Health. 2016;29(6):927-36, https://doi.org/10.13075/ijomeh.1896.00781.

62. Lipponi G, Lucantoni C, Antonicelli R, Gaetti R. Clinical and electromyographic evidence of carpal tunnel syndrome in a hypertensive patient with chronic beta-blocker treatment. Ital J Neuro Sci. 1992;13:157-9, https://doi. org/10.1007/BF02226965. 
63. Emara MK, Saadah AM. The carpal tunnel syndrome in hypertensive patients treated with beta-blockers. Postgrad Med J. 1998;64:191-2, https://doi.org/10.1136/pgmj. 64.749.191.

64. Ashworth N. Carpal tunnel syndrome. BMJ Clin Evid [Internet]. 2014 [cited 2016 Aug 1]. Available from: http:// clinicalevidence.bmj.com/x/systematic-review/1114/overview.html.
65. Niver GE, Ilyas AM. Carpal tunnel syndrome after distal radius fracture. Orthop Clin North Am. 2012;43:521-7, https://doi.org/10.1016/j.ocl.2012.07.021.

66. Heim D, Stricker U, Rohrer G. [Carpal tunnel syndrome after trauma]. Swiss Surg. 2002;8:15-20, https://doi.org/ 10.1024/1023-9332.8.1.15. German.

This work is available in Open Access model and licensed under a Creative Commons Attribution-NonCommercial 3.0 Poland License / Ten utwór jest dostępny w modelu open access na licencji Creative Commons Uznanie autorstwa - Użycie niekomercyjne 3.0 Polska - http://creativecommons.org/ licenses/by-nc/3.0/pl/deed.en. 